\title{
BIRD NUMBERS ON TUNDRA IN BAFFIN ISLAND
}

\author{
Adam Watson*
}

\section{Introduction}

$\mathbf{V}^{\mathrm{s}}$ ERY few people have counted the numbers of arctic birds since the pioneer study in Greenland by Longstaff (1932). When reviewing work on bird numbers Udvardy (1957) found only three papers dealing with the North American tundra. There is therefore a need for more work in this field by expeditions to the North. The present paper describes the study of bird numbers that I did while a member of the expedition of the Arctic Institute in 1953.

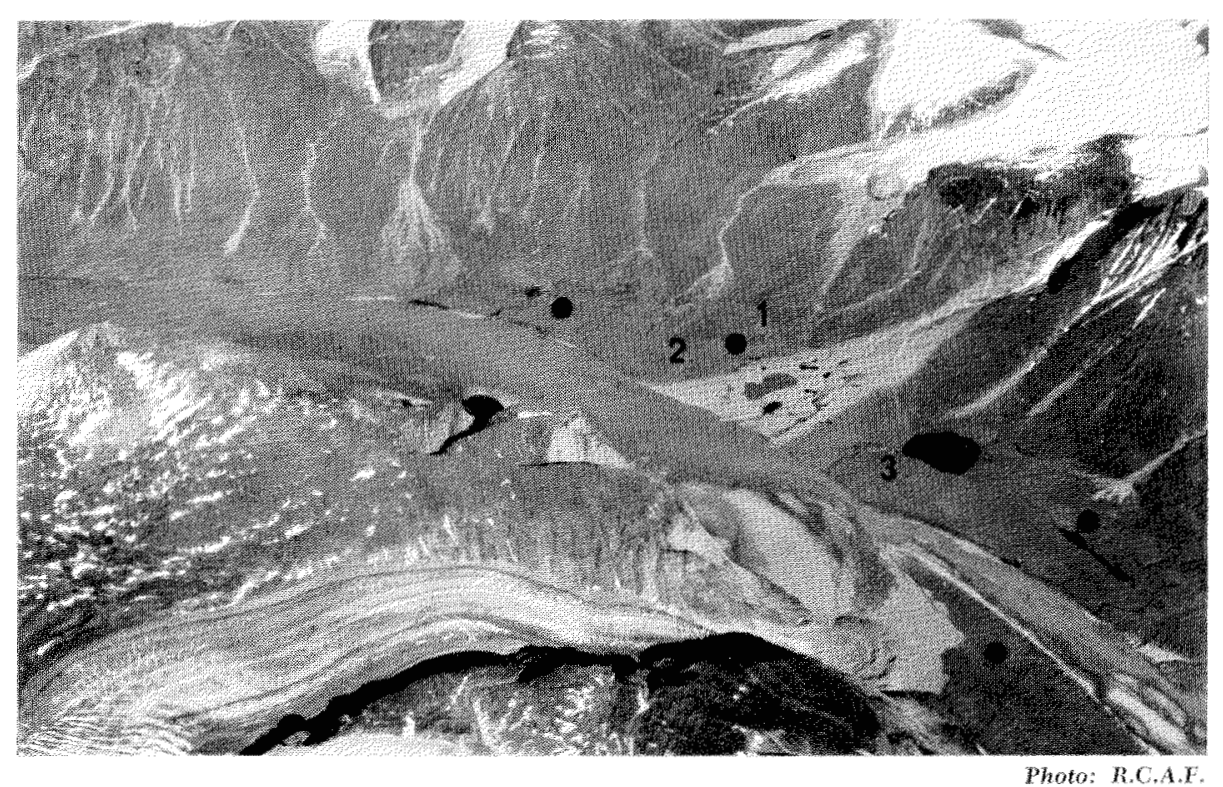

Fig. 1. Aerial photograph of Penny Highland and Owl Valley. (1) Biological camp, (2) centre of main survey area, (3) area of peak density of longspurs; dots denote nests of snowy owls.

A report by Baird (1953), the leader of the expedition, included notes on weather and vegetation, and a map of the area. The expedition worked from May till September in the Penny Highland of Cumberland Peninsula, at about $67^{\circ} \mathrm{N}$. on the east side of Baffin Island. There are many glaciated

*Nature Conservancy Unit of Grouse and Moorland Ecology, Natural History Department, Marischal College, Aberdeen, Scotland. 
and snow-capped mountains rising to $2000 \mathrm{~m}$. in this peninsula, and a relatively small area of low, well-vegetated ground (Fig. 1). Our biological camp was in Owl Valley, about $25 \mathrm{~km}$. from the nearest fiord on the coast. The average limit for continuous vegetation was roughly $350 \mathrm{~m}$.

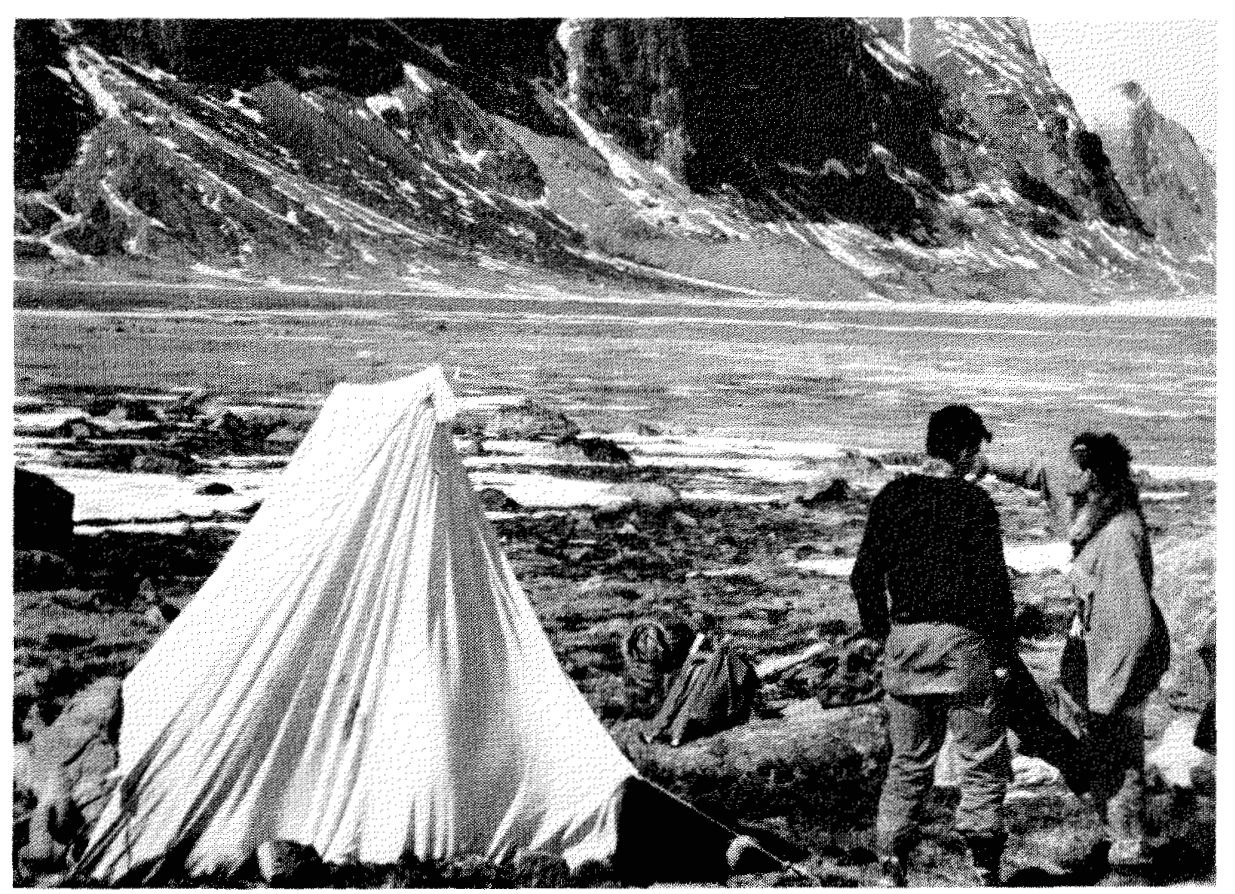

Fig. 2. The study area in mid-June, showing the wet grassy plains and the boulderstrewn grass heath near the camp.

\section{The study area}

This occupied 1 square mile (260 hectares) near our camp at altitudes of from 150 to $200 \mathrm{~m}$. A 40-hectare strip by the river had a dry sandy soil, with very few boulders, a small pond, and a fairly uniform vegetation of short grass. Above this strip was a 160 -hectare area of flat, wet ground, with grasses and sedges and very few boulders (Fig. 2). The upper 60 hectares were a gentle slope with many boulders, drier than the flats below and covered mainly with grass, small willows less than $40 \mathrm{~cm}$. high, and some heathy patches. This upper part merged with Cassiope and Dryas heath along the steepening, boulder-strewn mountain side. There were no stretches of dry heath without boulders in the study area, but I made a count on a 40-hectare area of dry heath about $1 \mathrm{~km}$. away (Figs. 3 and 4 ).

\section{Counting method}

The method was to plot on a detailed map, with reference to prominent landmarks, the exact position of every bird seen. This is the standard method 
for finding the absolute number of land birds on a small area (Udvardy 1957). I found directions with a prismatic compass and distances by pacing. In the course of other work I also spent many hours of continuous observation from ground vantage points, and this gave another opportunity for checking numbers and positions. I lived on the study area for 2 months, and since I walked over it every day and over some parts of it several times a day, I soon got to know where single birds and pairs were regularly to be seen. I did most of the work in mid-June, after the birds had all arrived and before they started breeding. Further work was done in July to estimate breeding success by looking for fledged broods.

On two densely populated 16-hectare areas within the main area I also did a detailed study that involved finding most nests and all broods. The first of these areas was on a slight slope with many boulders that was covered mainly with grass-heath and some willows, but at the top end with a patchwork of wet and dry heath. The second area lay on almost level ground alongside a large stream and was mainly covered with wet grassheath and many small willows, but it had only a few boulders.

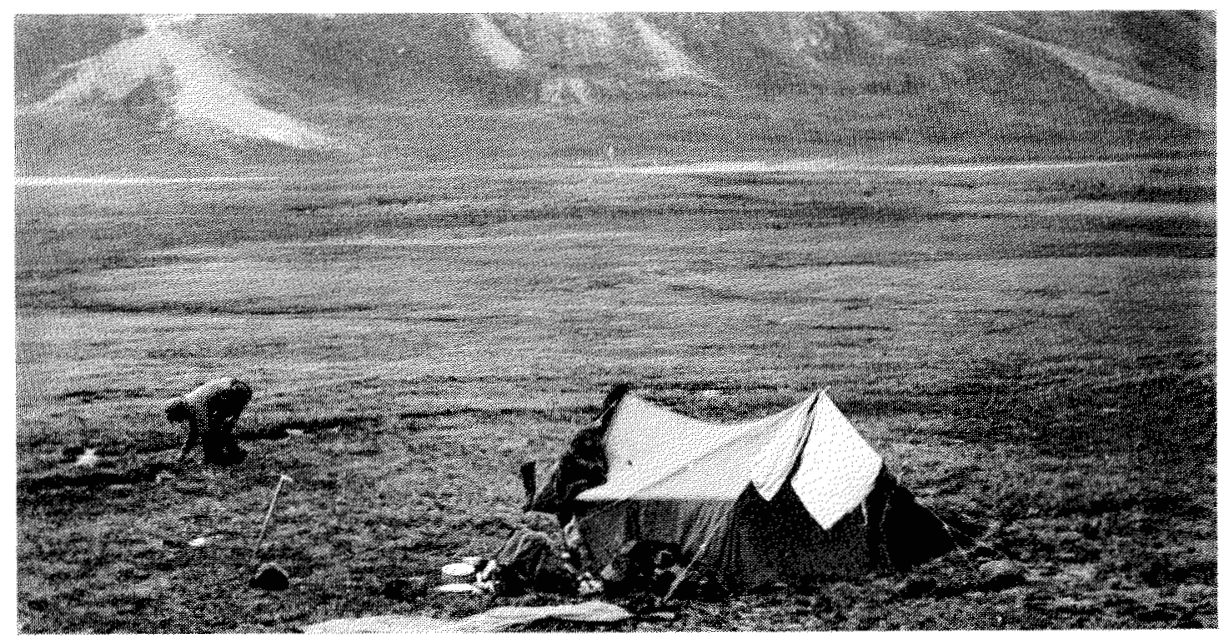

Fig. 3. An extensive area of dry grassy plains near the mouth of Owl River.

\section{Numbers of birds}

There were about 400 adult birds (Table 1) on the study area in mid-June, or roughly 60 per 40 hectares. Besides the residents various other birds visited the area. Most of the redpolls (Acanthis flammea and hornemanni) wandered about in small flocks; their numbers on different days varied from two to twenty, with an average of eight. About ten glaucous gulls (Larus hyperboreus) frequented the river, often outside the area. Gyr falcons and peregrine falcons (Falco rusticolus and peregrinus) sometimes flew over and other birds were seen more rarely; these are not included in the total. 
The only resident predators were a pair of snowy owls (Nyctea scandiaca), which fed almost entirely on lemmings. We saw no tracks or other signs of foxes (Alopex lagopus) or weasels (Mustela erminea). Predation on the passerine birds must therefore have been negligible.

Table 1. Number of adult birds on a square mile (260 hectares) in Cumberland Peninsula.

\begin{tabular}{lccccc}
\hline & $\begin{array}{c}\text { Pairs } \\
\text { seen }\end{array}$ & $\begin{array}{c}\text { Nests } \\
\text { found }\end{array}$ & $\begin{array}{c}\text { Fledged } \\
\text { broods seen }\end{array}$ & $\begin{array}{c}\text { Unmated } \\
\text { cocks }\end{array}$ & $\begin{array}{c}\text { Total } \\
\text { adults }\end{array}$ \\
\hline Snowbunting & 38 & 11 & 32 & 10 & 86 \\
Lapland longspur & 99 & 6 & 60 & 39 & 237 \\
Redpoll & 1 & 0 & 1 & & 8 \\
Horned lark (Eremophila & 3 & 0 & 2 & 0 & 6 \\
$\quad \begin{array}{l}\text { Watpestris) } \\
\text { Snater pipit }\end{array}$ & 19 & 2 & 14 & & 38 \\
$\begin{array}{l}\text { Glaucowl owl } \\
\text { Baird's sandpiper }\end{array} \quad 1$ & 1 & 1 & 0 & 2 \\
$\quad$ Erolic bairdii) & 0 & 0 & 0 & 0 & 10 \\
\hline \multicolumn{1}{c}{ Totals } & 1 & 0 & 0 & 0 & 2 \\
\hline
\end{tabular}

Tables 2 and 3 show the numbers of birds on different habitats in the main area and on the two small areas studied in more detail. Obviously, it could be misleading to do a single count on a large area without considering habitat selection. For example, Lapland longspurs (Calcarius lapponicus) were abundant on grass-heath with plenty of small willows, but less common on sandy grassy flats, on very wet grass devoid of shrubs, and on dry heath where they were outnumbered by pipits (Anthus spinoletta) and redpolls. Snowbuntings (Plectrophenax nivalis) were common in both wet and dry

Table 2. Numbers of birds in different habitats.

\begin{tabular}{lcccc}
\hline & $\begin{array}{c}\text { Dry grassy flats } \\
\text { with one pond }\end{array}$ & $\begin{array}{c}\text { Wet grassy } \\
\text { and sedgy } \\
\text { flats }\end{array}$ & $\begin{array}{c}\text { Grass-heath } \\
\text { with boulders }\end{array}$ & $\begin{array}{c}\text { Dry heath without } \\
\text { boulders (outside } \\
\text { study area) }\end{array}$ \\
\hline Area in hectares & 40 & 160 & 60 & 40 \\
Snowbunting & 1 & 20 & 65 & 0 \\
Lapland longspur & 10 & 171 & 56 & 6 \\
Redpoll & 0 & 2 & 0 & 19 \\
Water pipit & 4 & 18 & 16 & 24 \\
Horned lark & 4 & 0 & 2 & 0 \\
Snowy owl & 0 & 2 & 0 & 0 \\
Baird's sandpiper & 2 & 0 & 0 & 55 \\
\hline \multicolumn{1}{c}{ Totals } & 21 & 213 & 139 & \\
\hline
\end{tabular}

places wherever boulders offered cracks or holes for nest sites, but they were elsewhere scarce or absent. The second of the small areas (Table 3) was suitable for longspurs, but the boulders were all too smooth or too far apart to offer nest sites for snowbuntings. The first of the smaller areas 
was suitable for snowbuntings, with its innumerable boulders of all sizes, but it was less suitable for longspurs, probably because there was too much dry heath and not enough willows in the wet places.

\section{Review of other arctic bird counts}

My results are compared with other arctic bird counts in Table 4. Though the overall bird density on Soper's (1940) areas was similar to that on my area, his areas held more geese and waders and fewer passerines. Soper's areas were mainly dry grass plains, a bare habitat that also held few passerines in Owl Valley. The density on Savile's (1951) area, excluding stretches of rock and water, was higher than on my area. However, since the descriptions show that these study areas were not all the same it is not surprising that average densities also varied.

Table 3. Numbers on two 16 -hectare areas studied in detail.

\begin{tabular}{lccccc}
\hline & $\begin{array}{c}\text { Nests } \\
\text { found }\end{array}$ & $\begin{array}{c}\text { Known } \\
\text { breeding } \\
\text { pairs }\end{array}$ & $\begin{array}{c}\text { Total } \\
\text { pairs }\end{array}$ & $\begin{array}{c}\text { Unmated } \\
\text { cocks }\end{array}$ & Total \\
\hline Snowbunting & 9 & 10 & 12 & 4 & 28 \\
Lapland longspur & 4 & 5 & 6 & 3 & 15 \\
Horned lark & 0 & 1 & 1 & 0 & 2 \\
Water pipit & 1 & 1 & 2 & 7 & 49 \\
\hline \multicolumn{1}{c}{ Totals } & 14 & 17 & 21 & 1 & 1 \\
\hline Snowbunting & 0 & 0 & 0 & 0 & 28 \\
Lapland longspur & 7 & 9 & 12 & 5 & 35 \\
Horned lark & 2 & 2 & 3 & 15 & 5 \\
\hline \multicolumn{1}{c}{ Totals } & 9 & 11 & & & 4 \\
\hline
\end{tabular}

Every study on variable ground should include estimates of the extent of major habitats, such as rock outcrops, water, sand or gravel areas, and so on. None of these features occupied an appreciable part of my area but the difficulties are illustrated by the following examples. Much of the heath

Table 4. Comparison of some arctic bird counts.

\begin{tabular}{|c|c|c|c|c|c|}
\hline Author & Locality & $\begin{array}{l}\text { Adults per } \\
100 \text { acres } \\
\text { (40 hectares) }\end{array}$ & $\begin{array}{c}\text { Area } \\
\text { (sq. miles) }\end{array}$ & $\begin{array}{l}\text { Passerines } \\
(\% \text { of total) }\end{array}$ & Description of area \\
\hline Longstaff & W. Greenland & 28 & 8 & 85 & Low-lying rocky moor \\
\hline Soper & S.W. Baffin & $44,61,71$ & $1,1,11 / 2$ & $13,15,41$ & $\begin{array}{l}\text { Mostly grass plain, some } \\
\text { heath, many ponds, some }\end{array}$ \\
\hline Savile & Chesterfield & 48 & 4 & 83 & $\begin{array}{l}\text { Grass and heath, includ- } \\
\text { ing a settlement, bare } \\
\text { rocks } 1.5 \text { sq. mi., ponds } \\
0.6 \text { sq. miles. }\end{array}$ \\
\hline Watson & S.E. Baffin & 61 & 1 & 97 & $\begin{array}{l}\text { Grass and heath, no } \\
\text { ponds or bare rock, many } \\
\text { boulders. }\end{array}$ \\
\hline
\end{tabular}


in Longstaff's (1932) area held at least one breeding pair per acre, though the average overall density was seven times smaller, and 3 per cent of the birds lived on or near fresh waters occupying 20 per cent of the total area. The density on much of Savile's (1951) area must have been almost twice the average figure that he gave ( 40 birds per 40 hectares), since half of the area was rock and water with hardly any birds.

Figures from British moorland at low altitudes are very similar to the figures from arctic tundra, at between 20 and 100 birds per 40 hectares (Lack 1935). There were about 20 birds per 40 hectares on a marshy moor near sea-level in arctic Norway (Jenkins 1953), and also on wet and dry heath in Lapland at $500 \mathrm{~m}$. altitude (Watson 1957), about the same density as on the Owl Valley grass plains. However, far greater densities have been recorded in Northern Eurasia, at least locally (Mikheiv 1939, Rowell 1957).

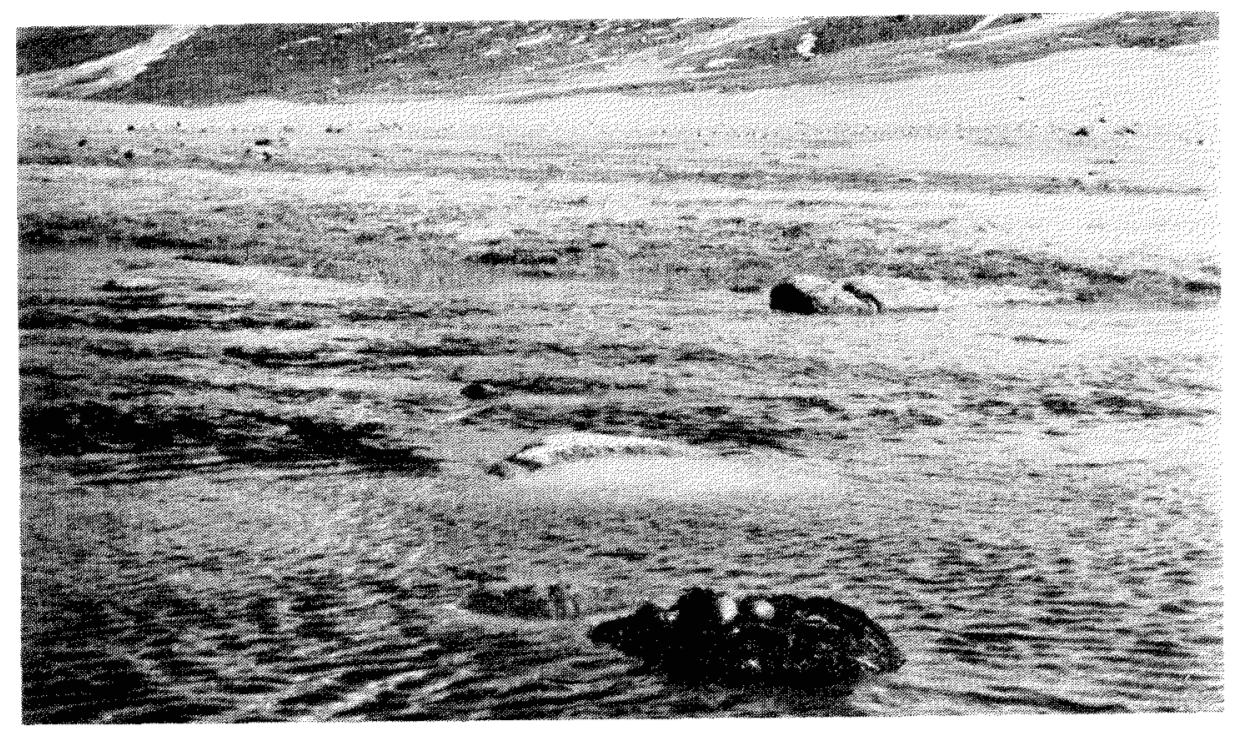

Fig. 4. Looking past the nest of a red-throated loon to an area of wet grass heath with many willows, a favourite habitat of the Lapland longspur.

\section{Sex ratio}

In most counts of arctic birds the population has been described in terms of the number of pairs. There was an excess of cock snowbuntings and longspurs in the Owl Valley area, with totals of 186 cocks and 137 hens. This was confirmed by detailed work on the two smaller areas (Table 3 ), which showed cock to hen totals of 17:12 for snowbuntings and 25:18 for longspurs. In the 40-hectare area of dry heath where the redpolls were breeding, there were 11 cocks and 8 hens. The overall proportion of cocks for all three species was 57 per cent. The sex ratios for pipits are less reliable since I often could not distinguish cock and hen. 
Almost all snowbuntings and longspurs in less favourable habitats, where they did not breed, were unmated cocks. Of the many snowbuntings that were seen high on the ice caps, on barren stone fields and glaciers, on open grasslands and sand dunes on the valley floor, nearly all were unmated cocks. Similarly nearly all the longspurs on the higher mountain slopes were cocks. The birds in the valley and on the mountain slopes sang loudly in the same places and obviously had territories there, but presumably these unfavourable habitats were not productive enough to support a breeding pair.

Wynne-Edwards (1952) found an excess of cocks in six passerine species that bred in central Baffin Island, but there seemed to be none unmated in Longstaff's Greenland area (Nicholson 1930.) Both D. NethersoleThompson (to be publ.) and I have independently noticed an excess of cock snowbuntings during the summer on their breeding range in the mountains of Scotland.

\section{Breeding success and non-breeding}

Breeding success can be seen in Table 1 by comparing the number of fledged broods with the number of pairs. Sixty-nine per cent of the pairs reared young, but if the unmated cocks are also included, only 60 per cent of the birds in the area bred successfully.

It was difficult to ascertain if pairs were non-breeding, since they might have bred and lost all their eggs or young without their having been found. However, non-breeding appears very likely where the proportion of pairs without eggs or young was very high, as in the aquatic birds.

Two pairs of red-throated loon (Gavia stellata) did not breed and the third pair deserted their nest soon after laying eggs. None of three pairs of old squaws (Clangula hyemalis) bred. I saw these birds every day after they arrived in the second week of June, and though they spent much time in sexual display, some pairs had already left the valley by the end of June and all by July 8 . Loons, including one identified common loon (Gavia inmer), were calling and displaying actively in a nearby valley in early June, but probably none bred, since only one was left on July 3 and none later in the month. Many glaucous gulls did not breed. All these birds were feeding on inland lakes and rivers, where the ice cover varied from 75 to 100 per cent in mid-June at the time of most active display. The ice all melted in the last 10 days of June, but by then the birds were no longer showing sexual display and some pairs had already gone. Non-breeding was probably a result of the very late spring. The weather was unusually bad in late May and the first 3 weeks of June, with snowfalls, high winds, cloudy skies, and frost nearly every night even at sea-level. It was impossible to know if there really were any non-breeding pairs of passerines, since the proportion of birds without eggs or young was much lower. Non-breeding was suspected in the nearby June Valley, where the snow was very deep in mid-June and where were many small flocks of both sexes of longspurs and redpolls in early July, but there was no proof of this. 


\section{Summary}

(1) During the summer of 1953 there were about 400 adult birds per square mile (260 hectares) in a Baffin Island mountain valley. Density varied greatly, from 5 birds per 10 hectares on a dry grassy area to 30 per 10 hectares locally on wet grass heath with boulders and willow shrubs.

(2) These results are compared with other arctic bird counts.

(3) There was an excess of cock redpolls, snowbuntings and Lapland longspurs. Nearly all passerine birds with territories on unfavourable habitat were unmated cocks.

(4) Most aquatic birds paired and displayed but did not breed, probably because of late ice in the rivers and lakes. Sixty-nine per cent of the pairs of passerine birds in the study area reared young.

\section{Acknowledgements}

I am grateful to P. D. Baird for inviting me to join his expedition in 1953, and to the McGill-Carnegie Arctic Program for generous financial help.

\section{References}

Baird, P. D. 1953. Baffin Island expedition, 1953; a preliminary field report. Arctic 6:226-51.

Jenkins, D. 1953. A study of habitat selection of birds in North-West Vesterålen. Sterna 9.

Lack, D. 1935. The breeding bird population of British heaths and moorlands. J. Anim. Ecol. 4:43-51.

Longstaff, T. G. 1932. An ecological reconnaissance in West Greenland. J. Anim. Ecol. 1:119-42.

Mikheiv, A. V. 1939. A contribution to the biology of the Lapland bunting Calcarius lapponicus. Zool. Zh. 18:924-38.

Nicholson, E. M. 1930. Field notes on Greenland birds. Ibis 6:280-314, 395-429.

Rowell, C. H. F. 1957. The breeding of the Lapland bunting in Swedish Lapland. Bird Study $4: 33-50$.

Savile, D. B. O. 1951. Bird observations at Chesterfield Inlet, Keewatin, in 1950. Can. Field Nat. 65:145-57.

Soper, J. D. 1940. Local distribution of Eastern Canadian arctic birds. Auk 57:13-21.

Udvardy, M. D. F. 1957. An evaluation of quantitative studies of birds. Cold Spring Harbor Symp. Quant. Biol, 22:301-11.

Watson, A. 1957. Notes on birds in arctic Norway. Sterna 28.

Wynne-Edwards, V. C. 1952. Zoology of the Baird expedition (1950). 1. The birds observed in central and south-east Baffin Island, Auk 69:353-91. 